\title{
A NEW RECORD OF Polistella (Polistes) SPECIES (Hymenoptera: Vespidae: Polistinae) WITH ITS NEST DESCRIPTION FROM TAY NGUYEN PLATEAU, VIETNAM
}

\author{
Nguyen Thi Phuong Lien \\ Institute of Ecology and Biological Resources, VAST, *phuonglientit@gmail.com
}

\begin{abstract}
One social wasp species of subgenus Polistella of the genus Polistes (Hymenoptera: Vespidae: Polistinae), Polistes meadeanus (von Schulthess), is recorded from Tay Nguyen plateau of Vietnam for the first time. This species can be distinguished from all other known species of subgenus Polistella from Vietnam by the metasomal tergum I distinctly longer than its apical width (1.4:1), and petiole of the nest is central, not terminal like almost other Polistella species. Nest structure of the species is also described in detail. Figures of female, male and nest are presented. The reported distribution areas of the species are confined to southern parts of the Southeast Asia, or Sundaland and the southeastern part of Indochina, and in this paper it is recorded from mainland for the first time. This record gives a great contribution to our knowledge on the distribution of the species, and supports to the hypothesis of the origin of the species, its origin is possibly in Sundaland with subsequent northward dispersal to Vietnam, but the Indochina origins and subsequent southward dispersal is not rejected.
\end{abstract}

Keywords: Vespidae, Polistes, Polistella, nest description, new record, Tay Nguyen, Vietnam.

\section{INTRODUCTION}

Among three Old World subgenera of the genus Polistes, namely Gyrostoma Kirby \& Spence, 1828, Polistella Ashmead, 1904, and Polistes, Latreille 1802, Polistella, with 85 valid species, is the largest in terms of the number of species and most widely distributed, occurring in most parts of the Old World except in Europe, Mediterranean Africa and the Arabian Peninsula [1, 2]. In Vietnam, faunal studies on Polistella wasps carried out since 2005 include Nguyen et al. (2005a,b) [3, 4], Nguyen et al. (2007a,b) [5], Nguyen \& Ta (2008) [7], Nguyen \& Pham (2011) [8] and Nguyen \& Kojima (2014) [9]. As a result of this work 23 species of Polistella have been recorded, comprising about one-fourth of Polistella species in the world; it shows a great species diversity in Vietnam.

Of the Polistella species, Polistes meadeanus (von Schulthess) was recorded from Malaysia (including Sabah, Sarawak) and Kalimantan of Indonesia [12]. Those places are peninsular and islands in southern part of South East Asia. None of the specimens was collected further north on the mainland before. In this paper, the species is recorded from Tay Nguyen plateau of Vietnam for the first time. Nest structure of the species is also described. This record greatly extends our knowledge of the distribution, and helps us to understand the origin of the species.

\section{MATERIALS AND METHODS}

The material examined in the present study is those specimens deposited in the collections of the IEBR.

The parts measured for the morphometric characters referred to in the descriptions are defined as follows: body length, the lengths of head, mesosoma and first two metasomal segments combined; the length of metasomal tergum 1, the distance in lateral view from the posterior end of the basal slit for the reception of the propodeal suspensory ligament to the posterodorsal end of the tergum.

The nest characters, including measurements of various parts given below, were examined after the immatures had been taken out and the nests had been air-dried. The length and thickness (minimum and maximum thicknesses at the mid-length) of a nest pedicel and the distance between opposite sides of a cell containing a pupa or having the trace of a cocoon cap ("cell width") were measured to the 
nearest $0.1 \mathrm{~mm}$ with vernier calipers. The thickness of cell wall was taken with a micrometer to the nearest $0.01 \mathrm{~mm}$. The terminology of nest characters follows Wenzel (1998) [13]. In the description of nest comb shapes, "ventral" and "dorsal" refer to the directions corresponding to cell openings and cell bottoms, respectively.

Photographic images were made with the Leica EZ4HD 3.0 MegaPixel Digital Stereo Microscope, using LAS exclusive microscopy software (LAS EZ 2.0.0); the plates were finished with Photoshop CS6.

\section{RESULTS AND DISCUSSION}

\section{Polistes meadeanus (von Schulthess, 1913)}

Parapolybia meadeana von Schulthess, 1913, Mitt. Schweiz. Entomol. Ges. 12: 161, female, male-"Kina Balu, Borneo, Perak, Sarawak" (London).

Polybia andrei du Buysson, 1913, Bull. Soc. Entomol. France 1913: 296, male"Malacca: Pérak" (Paris).

Polybia shelfordi du Buysson, 1913, Bull. Soc. Entomol. France 1913: 297, female"Kuching (Borneo)" (Oxford).

Material examined. 3 females, 1 male, Kon Ka Kinh NP, Mang Yang, Gia Lai, $14^{\circ} 11^{\prime} \mathrm{N}$, $108^{\circ} 17^{\prime} \mathrm{E}$, alt. $700 \mathrm{~m}$, Nest\#TN-2012-P-01, 13.vii.2012, NTP Lien; 7 females, 6 males, Kon Ka Kinh NP, K Bang, Kon Pne, Gia Lai, $14^{\circ} 23^{\prime} \mathrm{N}, 108^{\circ} 20^{\prime} \mathrm{E}$, alt. 847 m, Nest\#TN-2012P-02, 17.vii.2012, NTP Lien.

Diagnosis. This species can be distinguished from all other known species of the subgenus Polistella from Vietnam by the following combination of characters: metasomal tergum I distinctly longer than its apical width (1.4:1), and the petiole of the nest is central, not terminal like almost all other Polistella species.

The female and male structures of Polistes meadeanus were described in detail by Schulthess (1913) [11]. The female and male specimens we examined agreed well with the description by Schulthess (1913) [11] and Kojima et al. (unpublished) while the body sizes are slightly smaller than those described by
Schulthess and Kojima.

Female (fig. 1-3). Body length about 9.5$11 \mathrm{~mm}$, fore wing length about $11-12.5 \mathrm{~mm}$

Male (fig. 4-6). Body length about 8.5$10 \mathrm{~mm}$, fore wing length about $10-11.5 \mathrm{~mm}$

The nest Nest\#TN-2012-P-01 (fig. 7) was collected together with three females. The nest was attached to a broad leaf, at about $2.5 \mathrm{~m}$ above the ground, and has 22 cells, with three pupae, without eggs. One male emerged later when the nest was being kept in a nylon bag. The Nest\#TN-2012-P-02 (Fig. 8) was collected with seven adult female wasps; 6 males were emerged later. The nest was attached to a long and thin leaf, at about $2 \mathrm{~m}$ above the ground, and has 57 cells, with seven pupae. The structural and morphological characters are as follows: Comb tough, pliable "paper"-like in texture, more or less uniformly gray in cell wall, subcircular (about $19 \mathrm{~mm} \times 16 \mathrm{~mm}$ for Nest Nest\#TN-2012-P-01 and about $29 \mathrm{~mm} \times 27 \mathrm{~mm}$ for Nest\#TN-2012-P-02) in view from side of cell opening, expanded concentrically from the single petiole, with surface corresponding to cell bottom slightly convex. The nest Nest\#TN2012-P-01 has petiole single, central, attached to the border between bottoms of the first three cells, $3.9 \mathrm{~mm}$ long and $0.6 \times 0.9 \mathrm{~mm}$ thick at the mid-length, with thin central core of plant fibers, enlarged strictly with adult oral secretion, dark brown and lustrous, secretion coat expanded on comb back around the petiole and on substrate in about $2 \mathrm{~mm} \times 3 \mathrm{~mm}$ thin film. The petiole of the nest Nest\#TN-2012-P02 was lost while collecting, but was situated near the center of comb, first two cells having been constructed on its tip. Cells are generally arranged in regular rows, pentagonal at open end when surrounded by other cells, with free margins rounded; for the nest Nest\#TN-2012-P01 each cell expanded towards open end, 4.2 $\mathrm{mm}$ (range 3.8-4.6 $\mathrm{mm} ; \mathrm{n}=7$ ) wide at open end, $2.3 \mathrm{~mm}$ (range 1.8-2.7 mm; $\mathrm{n}=7$ ) wide at bottom and 12.3 (range 10.8-13.5 mm; $\mathrm{n}=7$ ) $\mathrm{mm}$ deep in full grown cells, cell wall about $0.07 \mathrm{~mm}$ thick; for the nest Nest\#TN-2012-P02 , each cell expanded towards open end 4.0 $\mathrm{mm}$ (range 3.7-4.4 $\mathrm{mm} ; \mathrm{n}=10$ ) wide at open 
end, $2.7 \mathrm{~mm}$ (range 2.5-3.0 mm; $\mathrm{n}=10$ ) wide at bottom and 11.8 (range 10.6-13 mm; $\mathrm{n}=10$ ) $\mathrm{mm}$ deep in full grown cells, cell wall about $0.9 \mathrm{~mm}$ thick. Cocoon caps greenish-yellow in nature, weathered with time to become pale yellow, produced beyond rim of cell by $0.5-3 \mathrm{~mm}$, slightly domed.

Distribution. Malaysia (including Sabah, Sarawak); Indonesia: Kalimantan; Vietnam (NEW RECORD): Kon Tum, Dak Lak.
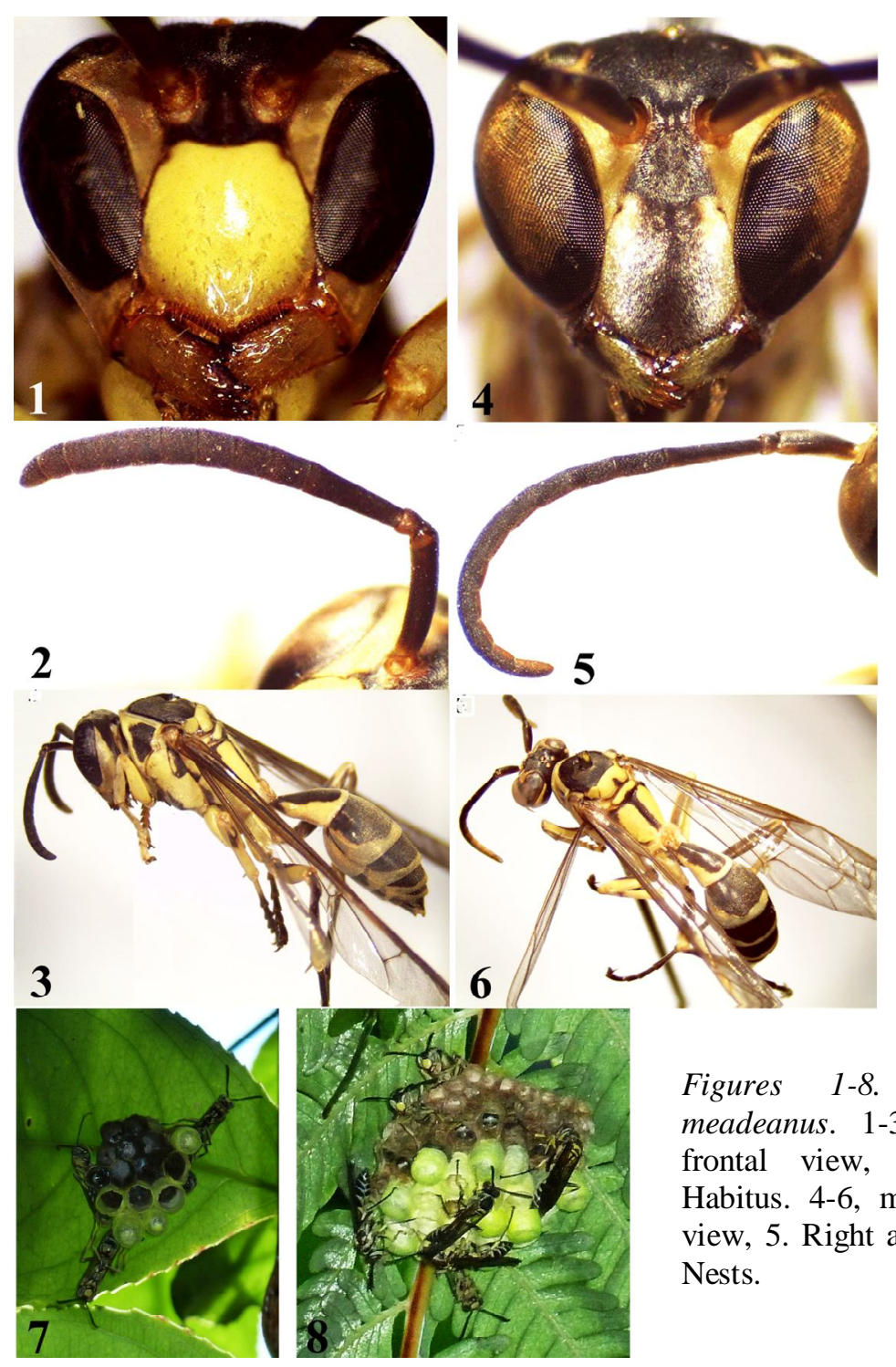

In Vietnam, Polistes meadeanus is recorded only from Tay Nguyen plateau in the southern part of the country. The reported distribution areas of the species are confined to southern parts of the Southeast Asia, or Sundaland and the southeastern part of Indochina. Its origin is

possibly in Sundaland with subsequent northward dispersal to Vietnam; but Indochina origins and subsequent southward dispersal cannot be rejected.

Acknowledgments: I would like to thank James M. Carpenter for his comments and 
English proofreading on the MS. The present study was supported by the grant from the Vietnam National Foundation for Science and Technology Development (NAFOSTED: no. 106-NN.05-2014.40) to the author.

\section{REFERENCES}

1. Carpenter J. M., 1996a. Phylogeny and biogeography of Polistes. In: Turillazzi, S. \& West-Eberhard, M. J. (Eds.), Natural History and Evolution of Paper-Wasps. Oxford University Press, Oxford, pp. 18-57.

2. Carpenter J. M., 1996b. Distributional checklist of species of the genus Polistes (Hymenoptera: Vespidae; Polistinae, Polistini). American Museum Novitates, 3188: 1-39.

3. Nguyen T. P. Lien, Kojima J. \& Saito F., 2005a. Survey of social wasps (Hymenoptera: Vespidae) in Xuan Son and Cat $\mathrm{Ba}$ National Parks. Proceedings of the National Conference on Life Sciences, Hanoi Medical University. Agricultural Publishing House, Hanoi: 218-220. (Vietnamese, summary in English).

4. Nguyen T. P. Lien, Saito F., Kojima J., Carpenter J. M., 2005b. An annotated distributional checklist of social wasps (Hymenoptera: Vespidae) of Viet Nam. Proceedings of the $1^{\text {st }}$ national workshop on ecology and biological resources. Agricultural Publishing House, Hanoi: 129137 (Vietnamese, summary in English).

5. Nguyen T. P. Lien, Saito F., Kojima J., 2007. Species composition and distributional pattern of social wasps (Hymenoptera: Vespidae) in relation to altitude in Bach $\mathrm{Ma}$ National Park. Proceedings of the $2^{\text {nd }}$ National Scientific Conference on Ecology and Biological Resources. Agricultural Publishing House, Hanoi: 411-414. (Vietnamese, summary in English).

6. Nguyen T. P. Lien, Khuat D. Long, Do V. Lap, Luong V. Hao, 2007. Survey of bees and wasps (Hymenoptera) in Cuc Phuong National Park. Proceedings of the $2^{\text {nd }}$
National Scientific Conference on Ecology and Biological Resources. Agricultural Publishing House, Hanoi: 415-419. (Vietnamese, summary in English).

7. Nguyen T. P. Lien, Ta H. Thinh, 2008. Survey of social wasps (Hymenoptera: Vespidae) in Truong Son range, which belong to Quang Binh, Quang Tri, Thua Thien Hue and Quang Nam Provinces. Proceedings of the $6^{\text {th }}$ Vietnam National Conference on Entomology. Agricultural Publishing House, Hanoi: 964-968. (Vietnamese, summary in English).

8. Nguyen T. P. Lien, Pham H. Phong, 2011. Study of social wasps (Hymenoptera: Vespidae) in some natural reserves in northwestern Vietnam. Proceedings of the 6th Vietnam National Conference on Entomology. Agricultural Publishing House, Hanoi: 848-851 (Vietnamese, summary in English).

9. Nguyen L. T. P., Kojima J., 2014. Distribution and nests of paper wasps of Polistes (Polistella) in northeastern Vietnam, with description of a new species (Hymenoptera, Vespidae, Polistinae). Zookeys, 368: 45-63.

10. Nguyen L. T. P., Kojima J., Saito F., 2011. Polistes (Polistella) wasps (Hymenoptera: Vespidae: Polistinae) from mountainous areas of northern Vietnam, with description of five new species. Zootaxa, 3060: 1-30.

11. Schulthess A. von., 1913. Parapolybia Saussure Vespidae sociales. Mitteilungen der Schweizrischen Entomologischen Gesellschaft, 12: 161-162, pls. 2, 12 and 13.

12. Vecht J. van der., 1966. The East-Asiatic and Indo-Australian Species of Polybioides Buysson and Parapolybia Saussure (Hym., Vespidae). Zoologische Verhandelingen, Leiden, 82: 3-42.

13. Wenzel J. W., 1998. A generic key to the nests of hornets, yellowjackets, and paper wasps worldwide (Vespidae: Vespinae, Polistinae). American Museum Novitates 3224: 1-39. 


\title{
GHI NHẬN MỚI VỀ MỘT LOÀI ONG BĂTT MỒI THUỘC PHÂN GIỐNG Polistella (Polistes) (Hymenoptera: Vespidae: Polistinae) VÀ CẤU TRÚC TỔ CỦA LOÀI NÀY Ở KHU VỰC TÂY NGUYÊN, VIẸTT NAM
}

\author{
Nguyễn Thị Phương Liên \\ Viện Sinh thái và Tài nguyên sinh vật, Viện Hàn lâm KH \& CN Việt Nam
}

\section{TÓM TẮT}

Phân bố của loài ong bắt mồi Polistes meadeanus thuộc phân giống Polistella của giống Polistes (Hymenoptera: Vespidae) ở Tây Nguyên lần đầu tiên đã được ghi nhận cho khu hệ các loài ong xã hội bắt mồi thuộc họ Ong vàng ở Việt Nam. Loài này có các đặc điểm khác so với các loài thuộc phân giống này ở Việt Nam đốt bụng thứ nhất dài hơn chiều rộng rõ rệt $(1,4: 1)$ và cuống tổ nằm ở trung tâm chứ không nằm lệch về một phía như cuống tổ của các loài khác thuộc cùng phân giống. Tổ của loài này cũng được mô tả chi tiết trong bài báo. Trước đây loài này chỉ được ghi nhận ở các vùng đảo và bán đảo phía nam của khu vực Đông Nam châu Á, lần đầu tiên loài này được ghi nhận ở Việt Nam cũng là ghi nhận ở đất liền. Ghi nhận này đóng góp một phần cho những hiểu biết về phân bố của loài này trên thế giới. Cùng với những ghi nhận về phân bố của loài trước đây ở Inđônêxia và Malayxia, hai giả thuyết được đưa ra, đó là Sundaland có thể là trung tâm phát sinh của loài này và sau đó chúng phát tán về phía Bắc đến Việt Nam, còn một giả thuyết khác cũng được xem xét đó là loài này có trung tâm phát sinh ở khu vực Đông Dương và từ đây chúng phát tán đến các bán đảo và các đảo ở phía nam.

Tù khóa: Vespidae, Polistes, Polistella, ghi nhận mới, cấu trúc tổ, Tây Nguyên, Việt Nam.

Ngày nhận bài: 29-10-2014 